\title{
Optics, Aged Witnesses and Aged Defendants: Habré at the Extraordinary African Chambers
}

\author{
Samuel Matsiko \\ Syrian Legal Network Amsterdam, Faculty of Law, University of Amsterdam, \\ Nieuwe Achtergracht 166, 1018 WV Amsterdam, The Netherlands \\ matsikosam@gmail.com
}

\begin{abstract}
The prosecution of international crimes in domestic and international criminal justice systems may involve aged defendants. Such prosecutions often implicate aged witnesses as well. There is a dearth of literature not only on the expressive value and optics of punishing aged defendants but also on the role of aged witnesses in the trial process. The need to interrogate these optics and perceptions - be it from an empirical or a theoretical perspective - is not only necessary, it is also timely. This article assesses the prosecution of Chadian dictator Hissène Habré in 2015-2016 at the Extraordinary African Chambers. This trial not only concerned an aged defendant, but also over 90 witnesses, the majority of whom was aged. This article explores the dialectics between the optics of punishing aged defendants and the optics of aged witnesses at the Habré trial.
\end{abstract}

\section{Keywords}

aged defendants - appearance - justice - optics - visualities - witnesses

\section{Introduction}

On 30 May 2016 the judges of the Extraordinary African Chambers delivered a guilty verdict against 74-year-old Hissène Habré, former Chadian president, for crimes committed during his repressive regime. The Habré trial did not only involve an aged defendant; it also involved over 90 witnesses, the majority of whom were aged. This was a trial of historical crimes, injustices, and late 
justice for atrocities committed between 1982 and 199o. This article explores the dialectics between the optics of punishing aged defendants and the optics of aged witnesses in the trial procedure, with specific reference to aged witnesses in the Habré case at the Extraordinary African Chambers.

Sharon Weill, Kim Thuy Seelinger, and Kerstin Bree Carlson, in their edited volume The President on Trial: Prosecuting Hissène Habré, ${ }^{1}$ argue that by some accounts, this trial and conviction constitute the most significant achievement of international criminal justice in the past decade. Establishing an ad hoc tribunal and commencing a trial against a deposed African head of state was an extraordinary and arguably unlikely success. The ad hoc tribunal set up in Senegal exceeded expectations, working on time, within budget, with no murdered witnesses or witness interference. ${ }^{2}$

Most of the literature on the Habré trial focuses on the judicial achievements of the Extraordinary African Chambers in Senegal. There is little, if any, conversation on the aesthetics and optics of prosecuting an aged defendant while relying on the voices of aged witnesses. There is also no discussion as to who an aged defendant is within the African context. This article steps into this gap.

Appearance of Justice or Visible Justice?

'Justice should not only be done, it must also be seen to be done.' Lord Chief Justice Hewart's remarks now resonate throughout the common law world and beyond ${ }^{3}$ and illustrate what is generally referred to as the theory of appearance. ${ }^{4}$ The appearance of justice and visualities of justice have an impact on perpetrators, victims, court officials, and even journalists who tell the stories of these visualities.

Whereas the dictum 'justice should be seen to be done' situates within the context of judicial independence and impartiality, it has migrated into the field of international criminal law, where some authors have labeled it as 'the power of visible justice'. ${ }^{5}$ Antonio Cassese stated that 'Justice must not only be done

1 S. Weill, K.T. Seelinger and K.B. Carlson (eds.), The President on Trial: Prosecuting Hissène Habré (Oxford University Press, New York, NY, 2020).

2 Ibid.

$3 \quad R$ v. Sussex Justices; Exparte McCarthy [1924] 1 KB 256, 259.

4 R. McKoski, 'The Overarching Legal Fiction: 'Justice Must Satisfy the Appearance of Justice", 4 Savannah Law Review (2017) 51-70, p. $5^{2}$.

5 Weill et al., supra note 1, p. 272. 
but must be seen to be done, it is not enough for the International Tribunal simply to administer international criminal justice impartially and with due regard for the rights of the accused. It must also carry out this activity under the scrutiny of the international community. ${ }^{6}$ Some authors further note that '[i]mages of international criminal justice today are distributed broadly, in particular by the institutions themselves in their public information and outreach policies.' ${ }^{7}$ For Justice to be seen to be done we thus ought to interrogate the images, visualities, and optics of justice and power actors. This is the premise of this paper.

Who is an aged defendant? Who is an aged witness? How old is old? Caroline Davidson argues that age evaluation depends on where one is and on the particular reason why age is on the table. Put differently, age must be contextualized. Davidson states that in the United States, for example, most writings about age define 'elderly' prisoners as aged $5^{\circ}$ and older. ${ }^{8}$ By contrast, legislation in several South American countries providing for alternative forms of incarceration for the elderly tends to use the age of 70 as the cut-off. The Inter-American Convention on Protecting the Human Rights of Older Persons defines 'an older person' as a person over the age of 60 unless the legislature has provided otherwise but in any event no greater than $65^{.9}$

In the context of the present contribution, the question must thus be asked: how old is old within the African context? Who is an aged defendant and who is an aged witness? Several regional African human rights instruments have attempted to determine who is an aged person. Two such instruments particularly stand out: the Protocol to the African Charter on Human and Peoples'

6 A. Cassese, 'Foreword by the former President of the International Criminal Tribunal for the former Yugoslavia, 321 International Review of the Red Cross (1997) 6o1-6o2, p. 602.

7 Weill et al., supra note 1, p. 273 .

8 C. Davidson, 'Aging Out: Elderly Defendants and International Crimes', 61Virginia Journal of International Law (2020) 57-110, p. 70.

9 Article 2, Inter-American Convention on the Protection of Older Persons, available online at http://www.oas.org/en/sla/dil/docs/inter_american_treaties_A-7o_human_rights_older_ persons.pdf (accessed 19 November 2020). 
Rights on the Rights of Older Persons ${ }^{10}$ and the AU Policy Framework and Plan for action of the Ageing. ${ }^{11}$

Adopted in 2016, the Protocol has only gathered three ratifications-from Benin, Lesotho, and recently Ethiopia ${ }^{12}$ - and has thus yet to come into force. Still, its provisions offer an important insight into the notion of age within the African context. Its Article 1 provides that the term 'older persons' means those persons aged 60 and above, as defined by the 1982 United Nations Plan of Action on Ageing ${ }^{13}$ and the 2002 AU Policy Framework and Plan of Action on Ageing. ${ }^{14}$ It also specifies that aging means any process of getting old from birth to death. The Protocol further clarifies that the words 'aged', 'older persons' and 'elderly' shall be construed to have the same meaning as older persons. Within the African context, aged defendants or aged witnesses are thus generally aged 60 and above.

Yet, for the purposes of criminal justice system(s), age should not be restricted to numerical figures and ought to take into account the time that has elapsed since the crimes were committed. Further, age should be construed as possibly influencing personalities, feelings and possibly attitudes in court. In 'Why Testify? Witness Motivations for Giving Evidence in War Crimes Tribunal of Sierra Leone', ${ }^{15}$ Shapnee Stepakoff, and others demonstrate that, with increased maturity and aging, individuals develop a greater interest in altruistic motivations, such as contributing to the public good of the country. This was a particularly striking — and visible — aspect of the Habré trial during which some aged witnesses illustrated altruistic visualities. Within the African context, age is often construed with personal experiences rather than documentation and numerical data. For example, Mahamat Mour, aged 45, had

10 Article 1, Protocol to the African Charter on Human and Peoples' Rights on the Rights of Older Persons, available online at https://au.int/sites/default/files/treaties/36438treaty-oo51_-_protocol_on_the_rights_of_older_persons_e.pdf (accessed 19 November 2020). AU Policy Framework and Plan for action of the Ageing, available online at https://www. helpage.org/silo/files/au-policy-framework-and-plan-of-action-on-ageing-.pdf (accessed 19 November 2020).

12 See 'Ethiopia ratifies the Africa Union Protocol on the Rights of Older People', available online at https://www.helpage.org/newsroom/latest-news/ethiopia-ratifies-the-africa-unionprotocol-on-the-rights-of-older-people (accessed 19 November 2020).

13 See Vienna International Plan of Action on Ageing, endorsed by the United Nations General Assembly, Resolution 35/51 (1982), available online at https://www.un.org/development/ desa/ageing/resources/vienna-international-plan-of-action.html (accessed 18 August 2021). See https://www.un.org/esa/socdev/ageing/documents/implementation/AUFramework Book.pdf (accessed 18 August 2021).

15 S. Stepakoff, G.S. Reynolds, S. Charters and N. Henry, 'Why Testify? Witnesses' Motivations for Giving Evidence in a War Crimes Tribunal in Sierra Leone', 8(3) International Journal of Transitional Justice (2014) 426-451, p. 449. 
testified about the enforced disappearance of his father in 1985 when he was 15 years old. Thirty years had elapsed since the commission of the crime to the time of testimony. He emphasized to the Chambers that he was looking for answers. In court, he asked Habré various questions: 'What did my father do? How did he die? Let him tell me what became of him?'. Age should therefore not be restricted to numerical figures.

\section{A Witness-Driven Approach}

Witnesses play an important role in both the investigation and the prosecution of atrocity crimes. International criminal courts and tribunals are witnesscentric or rely on a witness-driven approach in the prosecution of international crimes. One of the dominant features of modern international criminal courts and tribunals is the reliance on oral witness testimony. ${ }^{16}$ According to Wieviorka it is the Eichmann trial which initiated what she terms 'the era of the witness. ${ }^{17}$ Some authors have further noted that since the establishment of the ad hoc international tribunals in the early nineties and the establishment of international hybrid and domestic courts, witnesses have increasingly been perceived as the lifeblood of international criminal courts. ${ }^{18}$ Storytelling also has a marketing function - to tell the victims' story of injustice to the public and to gather legitimacy. What does this storytelling look like for the aged especially in the African context?

Despite a witness-driven approach to the prosecution and punishment of international crimes, there is a dearth of literature on the expressive value and optics of punishing aged defendants ${ }^{19}$ and on the role of aged witnesses,

16 G. Chlevickaite, B. Hola and C. Bijleveld, 'Thousands on the stand: Exploring trends and patterns of international witnesses', 32 Leiden Journal of International Law (2019) 819-836. See also N.A. Combs, Fact-Finding Without Facts-The Uncertain Evidentiary Foundations of International Criminal Convictions (Cambridge University Press, Cambridge, 2010), p. 12: 'the vast bulk of the evidence presented to the current international tribunals comes in the form of witness testimony'.

17 A. Wieviorka, The Era of the Witness, translated by Jared Stark (Cornell University Press, Ithaca, NY, 2006; original version: Plon, Paris, 1998).

18 P.M. Wald, 'Dealing with Witnesses in War Crime Trials: Lessons from the Yugoslavia Tribunal', 5 Yale Human Rights Development Law Journal (2002) 217-242, p. 219.

19 But see K. Tsinas, 'Prosecuting Asymmetrically: On Some 'Preconditions' of Criminal Liability of Aged Defendants for Atrocities', in this issue, pp. 43-62. See also K.J. Fisher, 'The Expressive Value of Prosecuting Aged Defendants: A Rebuke of Ageism', in this issue, pp. 63-85. 
prompting a need to interrogate the visualities and optics of aged witnesses in the prosecution of aged defendants. ${ }^{20}$

When dealing with aged witnesses there are several factors to consider. These are system variables and estimator variables. ${ }^{21}$ System variables are factors within the control of the criminal justice system. In the context of the Extraordinary African Chambers, such factors would include the number of witnesses who could testify, the existence of a witness protection program, or still the manner in which the Chambers assisted the witnesses. In contrast, estimator variables are factors beyond the criminal justice system's control that alter a witness's initial observation. These typically include the age and personal characteristics of the witness, the motivations, and the lived experiences of the witness, such as the visualities of the courtroom experience, the visual images of other witnesses, and of the perpetrators in court.

\subsection{The Extraordinary African Chambers}

The process to bring Hissène Habré to trial was a lengthy one. Back in February 200o, a Senegalese judge had indicted Habré on charges of torture, crimes against humanity, and 'barbaric acts'. The case never materialized due to political interference and matters jurisdiction by the courts in Senegal. In 2012, the Extraordinary African Chambers were created by means of an agreement between the African Union and the Government of Senegal ${ }^{22}$ to try international crimes committed in Chad from 7 June 1982 to 1 December 1990. The Extraordinary African Chambers were established by Statute. ${ }^{23}$ They comprised four chambers: an investigation chamber, with four Senegalese investigating judges; an indictment chamber, with three Senegalese judges; a trial

20 Noticeably, in the field of psychology, there are several studies that detail how old age impacts a witness's ability in a criminal trial. See e.g. H. Love, 'Aging witnesses: Exploring difference, inspiring change', 19 The International Journal of Evidence \& Proof (2015) 210-227.

21 G.L. Wells, 'Applied eyewitness testimony research: system variables and estimator variables', 36 Journal of Personality and Social Psychology (1978) 1546-1557.

22 R. Adjovi, "The Agreement on the Establishment of the Extraordinary African Chambers within the Senegalese Judicial System Between the Government of the Republic of Senegal and the African Union and the Statute of the Chambers', $5^{2}$ International Legal Materials (2013) $1020-1036$.

23 Statute of the Extraordinary African Chambers within the courts of Senegal created to prosecute international crimes committed in Chad between 7 June 1982 and 1 December 1990, available online at https://www.hrw.org/news/2013/og/o2/statute-extraordinaryafrican-chambers (accessed 22 November 2020). 
chamber, with two Senegalese judges and an international judge as President; and an appeals chamber, again with two Senegalese judges and an international President. The Chambers sat for 56 days from September to December 2015 .

\subsection{The Start of the Habré Trial}

When the trial started on 20 July 2015 in Dakar, Habré refused to appear before the Chambers, stating that he did not recognize them and challenging their legitimacy. The presiding judge ordered Habré to appear in court by force and police forces thus proceeded to bring him into the courtroom. Since Habré refused to recognize the Chambers, he did not allow his lawyers to defend him. The Chambers appointed lawyers to defend Habré throughout his trial and granted their request for additional time to prepare their case. ${ }^{24}$ The trial was adjourned for 45 days.

The first day after the recess, the court-appointed lawyers were present, but Habré still refused to emerge from his holding cell. Shortly thereafter, he was carried in - literally kicking and screaming — by young armed security guards. Habré's demeanor here is worth noticing as it seems to stand in sharp contrast with that of some other aged defendants. For instance, at the ECCC, Nuon Chea 'required assistance courtroom guards in order to sit down or stand up.' ${ }^{25}$ This difference in vitality and energy points to a diversity in the agency of the elderly, leading to distinct visualities of trials of ageing defendants. Yet, except for outbursts at the beginning and at the end of the trial, Habré remained silent throughout the hearings, seating in an office chair, suitable for his age, his face concealed behind a turban and sunglasses. The reasons for this clothing are unclear. While a parallel could here also be drawn with EccC defendant Nuon Chea who 'wore sunglasses to cover part of his aging face, ${ }^{26}$ Habré's reasons for 'hiding' behind sunglasses might possibly have been different. Indeed, never once did he turn to face the witnesses testifying against him, even when they attempted to address him directly. Were his concealing accessories a way to defy the Chambers and the witnesses?

24 A. Seck, 'A Long Walk to Justice: The Trial of Hissène Habré', 15 December 2015, available online at https://www.ijmonitor.org/2015/12/a-long-walk-to-justice-the-trial-of-hissenehabre/ (accessed 22 November 2020).

25 S. Fyfe, 'Negative Aesthetic Experiences of Prosecuting the Barely Alive', in this issue, pp. 23-42.

26 Ibid. 
The Investigative Chamber of the Extraordinary African Chambers conducted four missions to Chad from August to September 2013. During their visits, the judges gathered statements from 2500 direct and indirect victims and key witnesses, including former officials of the Habré government.

The outcome led to the selection of 96 witnesses who would testify before the Chambers: they included victim-witnesses, expert witnesses, forensic experts, and data analysts. Five of these witnesses ultimately could not testify due to procedural matters but, out of the 91 witnesses who did testify, mapping indicates that 61 witnesses were aged between 50 and 80 years old. Four witnesses did not know their dates of birth but appeared to be aged. 37 were aged between 60 and 80 years old, which is considered as 'aged' according to Article 1 of the Protocol to the African Charter on Human and Peoples' Rights on the Rights of Older Persons. The mapping of these aged witnesses was based on reading 55 summary witness reports from September 2015 to December 2015 published by Senegalese law students with the support of Trust Africa ${ }^{27}$ and watching transcribed YouTube videos of the witness testimonies. ${ }^{28}$ In mapping, some of the reports indicated dates of birth of the witnesses while other witnesses did not know their actual dates of birth. Witnesses Ali Alanaf, Khadijja Hassan Zidane, Gasto Alifa and Brahim Tass did not know their dates of birth but appeared aged. Tables 1-3 give a detailed breakdown — by age—of the witnesses who testified at the Habré trial.

\subsection{Expert Witnesses}

Aside from its heavy reliance on eye-witness testimonies, the Habré trial also featured a number of expert witnesses, including forensic experts. Experts from the Argentine Forensic Anthropology Team had carried out exhumations at a number of potential mass grave sites in Chad. Six forensic expert witnesses testified in court; these included forensic anthropologists, forensic archaeologists, forensic pathologists, forensic odontologists, and ballistic experts. Exhumations were carried out in Deli, in southern Chad, the site of an alleged killing of unarmed rebels in September 1984. The experts located 21 bodies, almost all military-aged men, most of whom were killed by gunshot. In Mongo,

\footnotetext{
27 Trust Africa, 'Daily summary reports of the Habré trial hearings before the Extraordinary African Chambers', https://www.trustafrica.org/en/resource/news/item/3212-extraordinarychambers-monitor, accessed 18 August 2021.

28 Interactive Forum on the Extraordinary African Chambers, https://www.youtube.com/ channel/UCgING8GqD65mKzs8NALpd2g/videos, accessed 18 August 2021.
} 
Name

1. Jaffe Hellen

2. Jean Alingué

3. Garba Akhaye

4. Mrs. Madjere Antoinette

5. Djede Romain

6. Mike Dottridge

7. Fadoul Kitir Zakaria

8. Halta Djimingaye.

9. Abdourahmane Gueye

10. Choukou Souguio

11. Faustin Balaam

12. Mbaidje Boukar

13. Zakaria Bachar

14. Adoum Abakar

15. GuengGuengSoulyemane

16. Kourtou Garmar

17. Kovonsouma alias Jean

18. Saria Asnègue Donoh

19. Mahamat HasssanAbakar

20. Gagolmo

21. Ngabouli Mallah

22. Dr. Nahor Ngawara

23. Zenaba Sile

24. Mahamat Haroun

25. Bandjim Bandoum,

26. ToudJibedje Marabi

27. Perich Pierre

28. Awada Guederké

29. Idriss Abdoulaye

\section{Azoumra}

3o. Hissein Robert Gambier

31. Mbaynasem Lakoubou

32. Mousa Outman

33. Laoukoura Mbainadjibe

34. Fatimé Toumlé,
Age

Total

83 years old

37 witnesses

78 years old

76 years old

73 years old

70 years old

70 years old

69 years old

69 years old

69 years old

69 years old

68 years old

67 years old

67 years old

65 years old

64 years old

64 years old

64 years old

64 years old

63 years old

63 years old

63 years old

63 years old

63 years old

63 years old

62 years old

62 years old

62 years old

62 years old

62 years old

61 years old

61 years old

61 years old

61 years old

6 o years old 
TABLE 1 Witnesses Aged 60 to 80 (cont.)

\begin{tabular}{ll} 
Name & Age \\
\hline 35. Haje Merami & 6o years old \\
36. Doumassen Ngardiguiro & 6 years old \\
37. Oumar Goudja & 6 years old \\
& 6 6o years old
\end{tabular}

TABLE 2 Witnesses Aged 5o to 60

\begin{tabular}{|c|c|c|}
\hline Name & Age & Total \\
\hline 1. Ngarnadji Djedanoum & 59 years old & 24 witnesses \\
\hline 2. Satta Gaye & 59 years old & \\
\hline 3. Djibrine Ahmat & 58 years old & \\
\hline 4. M.NeldiWaMoramgar & 58 years old & \\
\hline 5. Saboune Bichara & $5^{8}$ years old & \\
\hline 6. Doungous Batil & 57 years old & \\
\hline 7. Abaifouta Clement & 57 years old & \\
\hline 8. Berculait Oliver & $5^{6}$ years old & \\
\hline 9. Kaltouma Defala & $5^{6}$ years old & \\
\hline 10. Madjadoumbaye & $5^{6}$ years old & \\
\hline 11. Khamis Agboudja & 55 years old & \\
\hline 12. Agboudja & 55 years old & \\
\hline 13. José Luis & 55 years old & \\
\hline 14. Maybe Komadj & 55 years old & \\
\hline 15. Biso claudeia & 53 years old & \\
\hline 16. Ibrahim Moura & 53 years old & \\
\hline 17. Bassou Ngolo & $5^{2}$ years old & \\
\hline 18. Bechir Bichara & $5^{2}$ years old & \\
\hline 19. Prosper Kladoumngué & $5^{1}$ years old & \\
\hline 20. Maytolel Daoussin & $5^{1}$ years old & \\
\hline 21. Brahin & $5^{1}$ years old & \\
\hline 22. Moutede Djim Hyangar & 5 o years old & \\
\hline 23. Fatimé Sakine & 5 o years old & \\
\hline \multirow[t]{2}{*}{ 24. Patrick Ball } & 5 o years old & \\
\hline & 5 o years old & \\
\hline
\end{tabular}




\begin{tabular}{ll}
\hline Name & Age \\
\hline 1. Ginette Ngarbaye & Total \\
2. Manda René & 26 years old \\
3. Jorge Manuel & 49 years old \\
4. Hachim Sale & 49 years old \\
5. Ahmat Outman & 49 years old \\
6. Hassan Baugueri & 48 years old \\
7. Tanaka Tobin & 48 years old \\
8. Ginarte Anahi & 48 years old \\
9. Yacoub Haroun & 48 years old \\
10. Mercedes Salado & 48 years old \\
11. Mr. Ousmane & 47 years old \\
12. Djamhil Mariam & 47 years old \\
13. Kal Assoum & 47 years old \\
14. MianmbayeDjétoldia & 47 years old \\
15. Hadje Mahadjirie & 46 years old \\
16. Gassama Diop & 46 years old \\
17. Danile Fransen, & 46 years old \\
18. Mahamat Nour & 46 years old \\
19. Fadour Kitir & 45 years old \\
20. Madjikotrai & 45 years old \\
21. Ousmane Abakar & 45 years old \\
22. Hawa Brahim Faradj & 45 years old \\
23. Souleymane Abdalay & 43 years old \\
24. Dingammadji & 40 years old \\
25. Mr. Ngemadji & 39 years old \\
26. Omar Déby Itno & 38 years old \\
& 37 years old \\
&
\end{tabular}

in the center of Chad, the experts uncovered 14 bodies from another 1984 massacre. Clement Abaifouta, 57-year-old and president of the Association of Victims of the Crimes of the Hissène Habré Regime, testified that he was forced to bury the bodies of deceased detainees in mass graves. He was considered by most witnesses who appeared before the Extraordinary African Chambers as the main gravedigger of the DDS and his testimony added to the forensic visualities at the Habré trial. 
Expert witnesses at trial also included a date analyst-Patrick Ball-who had developed a database analysis of the atrocities perpetrated during Habré's regime. Focusing on the period from 31 May 1985 to 31 May 1988, the database enabled to draw objective conclusions on the mortality rate in the DDs. ${ }^{29}$ The expert witness explained the methodology employed to build the database: it consisted of determining the number of prisoners that entered and died each day at the DDS. The expert analysis was centered on the crude mortality rate and peak value and led to the conclusion that the mortality rate in DDS prisons was 90 to 400 times higher than the usual mortality rate of Chadians aged 15 to 6 o years between1985 and 1988. Moreover, this death rate was 1.3 to 4.5 times higher than that among American prisoners of war in Japan and 1.5 to 2.4 times higher than that among German prisoners of war in the Soviet Union. By revealing how brutal and murderous the Habré regime was, the presentation of this data at trial created in-court visualities of mortality. But these were not the only types of visualities at the Habré trial, as detailed below.

\section{$7 \quad$ Visualities at the Extraordinary African Chambers}

\section{1 $\quad$ Altruistic and Moral Visualities}

Aged witnesses and victims of conflicts as they mature and grow older may admittedly develop altruistic and moral perceptions. The above-mentioned study conducted by Stepakoff and others on why witnesses testify conducted in relation to the Special Court for Sierra Leone shows that, while younger witnesses experience an urge for emotional relief as they were not mature enough with the emotional resource to cope with experiences of conflict, older witnesses developed greater altruistic motivations such as contributing to the greater good of the country. ${ }^{30}$ While aged witnesses may thus develop a moral obligation, thereby creating moral visualities and altruistic visualities, expressions of right and wrong, it is however doubtful that moral and altruistic concerns are exclusive to aged defendants. A study of 87 prosecution witnesses

29 See Human Rights Data Analysis Group, 'HRDAG Testifies in Hissène Habré Trial', available online at https://hrdag.org/2015/og/23/hrdag-testifies-in-hissene-habre-trial/ (accessed 7 August 2021). For the database, see Patrick Ball, 'Mortality in the DDs Prisons in Chad, 19851988', Human Rights Data Analysis Group (24 August 2014), available online at https://hrdag. org/wp-content/uploads/2015/og/TD-Habre-en-Aug2014-FINAL1.pdf (accessed 7 August 2021).

See Stepakoff et al. supra note 15 . 
testifying at the International Criminal Tribunal for the former Yugoslavia (ICTY) reports that ninety per cent of them-regardless of their age-said that it was their 'moral duty to testify' to ensure the truth is told and acknowledged. ${ }^{31}$ The moral duty includes truth-telling, preventing future atrocities and honoring victims.

At the Habré trial, Bandjim Bandoum, a 62-year-old witness and once a top political police agent of the Documentation and Security Department (DDS) during the Habré regime, showcased altruistic visualities and moral aesthetics. The witness claimed that testifying was part of his personal journey because what he saw and heard stirred his conscience. He asserted that he was also doing this for his family: he explained that on several occasions, his wife had been stopped in the streets and finally received a gunshot wound. Following this, his son asked him if he had killed anyone while at the DDS. He replied that he would testify if there was a trial and 'he will know'. At trial, Bandjim Bandoum asked the victims for forgiveness before turning to Habré, sitting a few feet away, and saiying: 'I have lived up to my responsibility, now it is time for you to live up to yours'. Habré remained silent, his face covered up in a turban and sunglasses.

\subsection{Territorial Visualities}

It is important to understand the localities and geographies in which international criminal justice is produced, received, and perceived to identify the optics and territorial visualities of international criminal justice from Nuremberg, Tokyo, Sarajevo, The Hague, Arusha, Sierra Leone to Dakar. In the case at hand, one pressing question is: why was a Chadian dictator tried in Senegal for crimes committed in Chad? Rather tellingly for the purposes of the present article, Souleymane Gueng Gueng - who testified at the Habré trial at the age of 64 and thus as an aged witness according to the Protocol to the African Charter on Human and Peoples' Rights on the Rights of Older Persons - had been inspired by the principle of universal jurisdiction and the London arrest of former Chilean dictator Augusto Pinochet. He had filed a complaint - together with Dr. Fadoul Kitir Zakaria, who also testified against Habré at the age of 69-against Habré in Senegal in January 2000, that is, 15 years before the trial started. Souleymane GuengGueng was not new to these territorial visualities of international justice: he had contributed to the

$31 \quad$ E. Stover. The Witnesses: War Crimes and the Promise of Justice in The Hague (University of Pennsylvania Press, Philadelphia, PA, 2005) p. 71. 
Belgium v. Senegal case before the International Court of Justice ${ }^{32}$ and had also appeared before the United Nations Committee Against Torture. ${ }^{33}$

In the proceedings against Habré, territorial visualities were further illustrated by witnesses Mahamat Nour (45 years old) and Souleymane Abdalay Tahir (41 years old) who experienced Habré's atrocities while they were teenagers. As young adults and Belgian citizens of Chadian origin, they filed a case against Habré in Belgium, prompting the Belgian authorities to initiate a fouryear investigation before indicting Habré in 2005 and seeking his extradition. ${ }^{34}$ Interestingly, this led to the qualification of these witnesses as aged witnesses, not because of their numerical age but because of the time that had elapsed since the perpetration of the crimes.

\subsection{The Witness 'Who Runs Faster than Death'Visualities}

'I would rather die having spoken after my manner than speak in your manner and live.... The difficulty, my friends, is not to avoid death, but to avoid unrighteousness; for that runs faster than death. ${ }^{35}$

One of the highlights of the Habré trial was the testimony of 61-year-old Hissein Robert Gambier who had survived five years in different prisons under the Habré regime, earning the nickname 'the man who runs faster than death'. He testified that he counted 2053 detainees who died in prison. A particularly poignant moment of his testimony was his recollection of having covered himself with the blood of a Sudanese prisoner, who had died after having been subjected to Arbatachar, ${ }^{36}$ in an attempt to pretend to be dead and escape the harsh punishment that awaited him. The soldiers however found him out and informed their leader, Aba Moussa, who ordered his transfer to the Special Rapid Action Brigade (SBIR) where he was put in a cell with six detainees, all

32 See ICJ, Questions relating to the Obligation to Prosecute or Extradite (Belgium v. Senegal), Judgment, I.C.J. Reports 2012, p. 422.

33 Committee Against Torture Souleymane GuengGueng et al., CAT/C/36/D/181/2001 19 May 2006.Souleymane GuengGueng the victim plaintiff filed a complaint against Senegal with the UN Committee against Torture (CAT) for violations of the Convention against Torture and Other Cruel, Inhuman or Degrading Treatment or Punishment in April 2001. In May 2006 the UN Committee against Torture ruled that Senegal has violated the Convention against Torture by failing to prosecute or extradite Habré.

34 Human Rights Watch, 'Ex-Chad Dictator Indicted in Belgium-Hissène Habré to Face Extradition to Belgium for Human Rights Atrocities', 29 September 2005, available online at https://www.hrw.org/news/2005/o9/29/ex-chad-dictator-indicted-belgium-o (accessed 6 January 2021).

35 Socrates' Speech in Thomas G. West, Plato's "Apology of Socrates": An Interpretation, with a New Translation (Cornell University Press, Ithaca, NY, 1979).

36 See infra. 
aged 18 and above. The witness stated that the cell, which was sprayed with antiseptics, caused the death of 187 inmates among its 460 residents. He owed his salvation only to a small hole caused by the shrapnel on the door. It was through this little hole that he breathed. To physically demonstrate how his head was squeezed as he was tortured, he brought wooden sticks in court; a gesture which created mortality visualities and optics at the trial. Perhaps ironically, Hissein Robert Gambier is nearly blind because of the torture he endured; like many other victims who also testified against Habré, he could barely see the defendant.

\subsection{The Arbatachar Visualities}

Arbatachar, a torture method that involved tying all four of a prisoner's limbs behind their back to interrupt the bloodstream and quickly induce paralysis, was systematic in prisons and detention centers during the Habré regime. ${ }^{37}$ Many of the aged witnesses testified that they had been subject to the infamous arbatachar torture ${ }^{38}$ and almost all of them had directly or indirectly experience and witnessed arbachatar. The arbachatar visualities were seen during the trial as aged witnesses illustrated how they were tortured.

\subsection{Lifting of the Veil and Sexual Violence Visualities}

'He pretended to adjust his turban and looked at me out of the corner of his eye. When I saw him, I was looking at a monster. It was like looking at a man who has massacred all his children'39

Although the original charges against Habré did not include any mention of sexual violence, the Extraordinary African Chambers broke new ground by attempting to re-qualify the original charges to include rape and sexual

37 Mahamat Djibrine was one of the most feared torturers and chief architect of the arbatachar torture method. He was described as one of the 'most feared torturers in Chad' by a 1992 Chadian Truth Commission, available online at https://redress.org/news/no-redress-forex-dictators-victims-in-chad-african-commission-should-press-for-habre-era-reparations/ (accessed 6 August 2021). He was wanted by the Extraordinary African Chambers but Chad officials failed to hand him over to the Chambers.

38 See, e.g., the testimonies of Nyoma Kovonsouma Jean (64 years old), Hissein Robert Gambier (61 years old), Fadoul Kitir Zakaria (69 years old), Halta Djimingaye (69 years old), and Lakoubou (61 years old).

39 Ginnett Ngarbaye, 49 years old, Witness Testimony at the Extraordinary African Chambers, available online at https://www.theguardian.com/global-development/2016/sep/18/hissenehabre-chad-dictator-couragou s-rape-survivors-make-history (accessed 7 January 2021). 
violence crimes. This was the outcome of an amicus brief submitted by campaigners calling on the Judges to revise the charges against Habré to include sexual violence. In the final guilty verdict of May 2016 Habré was found guilty of committing rape and torture against Khadidja Hassan Zidane, Kaltouma Defala (59 years old), Haje Merami (6o years old), Houawa Birahim (43 years old), and Ginette Ngarbaye (49 years old), who had testified about having been sexually violated. One of the most salient stories was that of Zidane's, probably in her sixties when she testified. Referred to as 'red', she appeared before the court wearing a striking red-and-black headscarf, that created perhaps the greatest shockwave and caused a stir in the entire trial. She said she was a victim of sexual violence and had been raped by Habré. Although she was allowed to describe this ordeal in a private closed session, she still insisted on explaining what happened to her in open court, at one point offering to remove her clothing to show where she had been stabbed in the legs and genitals. Habré, largely hidden beneath his robes, did not appear to react; his right hand resting against his face, he continued to stare unflinchingly ahead as Zidane recounted her story. During cross-examination, a lawyer for the civil parties asked her, 'Why have you brought a photograph with you?' Zidane replied, 'I brought my photo so that Habré would recognize me because old age has not been kind to me'. Supported by an amicus curiae brief filed at the Chambers, Zidane's testimony led to the reclassification of charges against Habré to include sexual violence. 'This case is quite extraordinary in that not only do we have allegations of sexual violence committed by the defendant's subordinates, but we also have allegations of rape and sexual torture committed by Habré personally. This is rare', said Kim Thuy Seelinger.

Images of international criminal justice today are distributed broadly, in particular by the institutions themselves via their public information and outreach programs. Images and visual, verbal, textual, and symbolic communications play a key role in international criminal justice and this, for a variety of reasons among which the promotion of justice, deterrence, marketing, increase of credibility and legitimacy. Witness testimonies are an integral part of these visualities as they do contribute to the outreach goals of international criminal justice and to its posterity ambitions for future generations. Rather tellingly, before the start of the Hissène Habré trial, the Coalition and some donor countries pressed for maximum exposure while Hissène Habré's supporters opposed all broadcast. Until the eve of the trial, the arrangements for 
recording and broadcasting the hearings were up in the air. In the end, the trial was live-streamed and almost all the sessions were posted on the internet. The witness testimonies are still available on YouTube. Unlike any other international criminal trial, this trial was thus immensely public. International Justice must be visible or be seen to be visible. Seeing an aged Hissène Habré in a turban and sunglasses appearing in a courtroom, before Judges, victims, witnesses, and experts meant that international criminal justice was not only visible, it also seemed to be visible. 